\title{
Radiocarbon dating of a mammoth tusk fragment from Brorfelde, Denmark
}

\author{
LOTTE SELSING
}

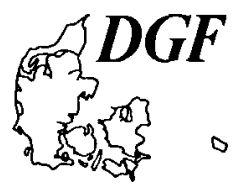

\begin{abstract}
Selsing, L. 1982: Radiocarbon dating of a mammoth tusk fragment from Brorfelde, Denmark. Bull. geol. Soc. Denmark. vol. 31, pp. 151-157. Copenhagen March 7th 1983. https://doi.org/10.37570/bgsd-1982-31-11

Fragments of three elephantine tusks have been found in ice transgressed fluvioglacial deposits at Bror-felde, northwestern Sjælland, Denmark. Four ${ }^{14} \mathrm{C}$ datings have been carried out on one of the fragments (Tusks 2) of a mammoth tusk (Mammuthus primigenius Blumenbach). They constitute the first radiocar-bon datings of Danish mammoth material. The age is given as the mean value of two collagen dates, $44300_{-1200}^{+1400}$ years B.P. Techniques of the applied dating procedures are given to elucidate contamination problems and to compare with ${ }^{14} \mathrm{C}$ datings of mammoth tusks from other localities in northwestern Europe. The date of the Brorfelde Tusk 2 should be regarded as a maximum age of the Brorfelde deposits. The date $44300+1200$ years B.P. of this tusk fragment corresponds relatively well with the earliest Middle Weichselian interstadial recorded in other areas.
\end{abstract}

Lotte Selsing, Archaeological museum in Stavanger, post-office box 478, N-4001 Stavanger, Norway. October 11th, 1982.

At Brorfelde, $10 \mathrm{~km}$ south of Holbæk, northwestern Sjælland, Denmark, more than $60 \mathrm{~m}$ of fluvioglacial deposits are covered by basal till. Geologic investigations (Selsing in prep.) indicate a Late Weichselian age for the deglaciation phase, corresponding to the fluvioglacial deposits, and for two succeeding ice advances (chronostratigraphic subdivision Mangerud \& Berglund 1978, Chaline, Mojski \& Meyer 1980).

An attempt shall here be made to date these sediments by way of radiocarbon dating of a mammoth tusk fragment found within the fluvioglacial deposits. Radiocarbon datings of mammoth remains, reindeer antler, wood and mollusc shells from Scandinavian deposits indicate Late Weichselian, Middle Weichselian or infinite ages (e.g. Berglund, Håkansson \& Lagerlund 1976, Heintz, Garnes \& Nydal 1979, Østmo in Nydal, Gulliksen \& Løvseth 1972, Sollid 1969, Krog \& Tauber 1974). A relatively young age of the Brorfelde specimen, i.e. within the application range of the ${ }^{14} \mathrm{C}$ method, would contribute important information of the chronostratigraphy of the area.
The elephantine tusk fragments from Brorfelde

Occasionally, elephantine bone, molar and tusk remains are found in the Danish glacigenic deposits. Nordmann published reviews of such finds (1921, 1942). An unpublished list by U. Møhl (Zoological Museum, Univ. of Copenhagen) from 1975 includes a total of about 85 mammoth finds (Berglund et al. 1976).

Fragments of three elephantine tusks have been found by Poul Andersen during work in the Mogenstrup Gravel and Mortarworks, Brorfelde. The finds are included in Møhl's list mentioned above, and have been examined by Møhl. ${ }^{14} \mathrm{C}$ datings of the best preserved of these tusk fragments (Tusk 2) will be presented here.

Tusk 1 was found in 1963 approximately $20 \mathrm{~m}$ below the surface of the fluvioglacial deposits in the fluvioglacial deposits. The tusk fragment is broken at both ends. Its length is about $40 \mathrm{~cm}$, and the maximum diameter of the (oval) crosssection at the ends is $6.7 \mathrm{~cm}$ and $7.0 \mathrm{~cm}$ respectively. The fragment probably derives from the middle part of a tusk.

The morphology of Tusk 1 gives no indication of species. The finding context suggests it de- 


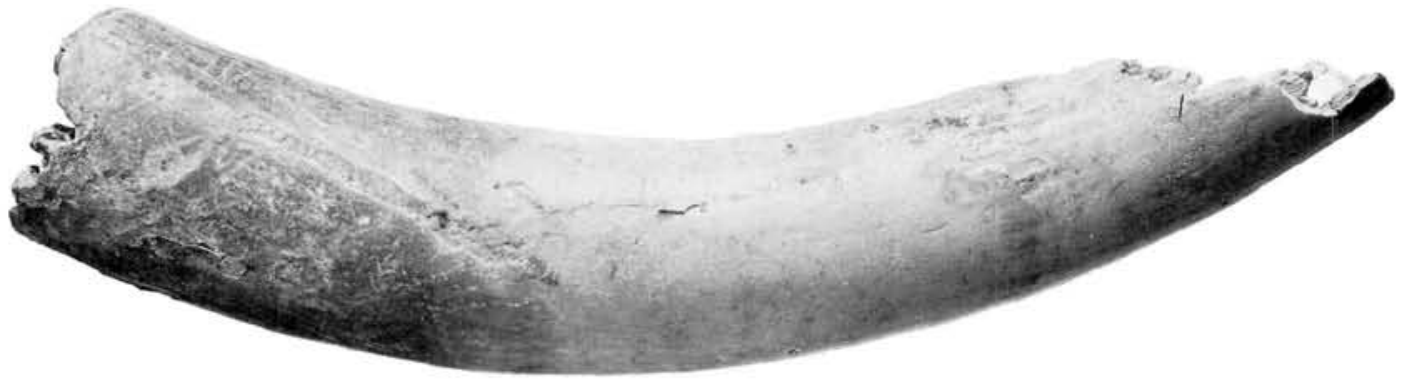

Fig. 1. Radiocarbon dated tusk fragment from Mammuthus primigenius Blumenbach (Tusk 2) found 1966 in Mogenstrup Gravel and Mortarworks, Brorfelde, northwestern Sjælland, Denmark. Length of fragment ca. $37 \mathrm{~cm}$. Photo: G. Brovad, Zoological Museum in Copenhagen.

rives from Mammuthus primigenius Blumenbach (Møhl pers. comm.). The specimen was well preserved upon finding. It has since been conserved, and is kept by Svend Andersen, Brorfelde.

Tusk 2 (fig. 1) was found in 1966 in the gravel sorting machinery. It also derives from the fluvioglacial sediments. The fragment is well preserved. Its length is about $37 \mathrm{~cm}$, the maximum diameter of the cross-section (oval) at each end is $5.7 \mathrm{~cm}$ and $7.0 \mathrm{~cm}$ respectively. Its curvature is vague. Møhl directed my attention to the fact that the fragment exhibits the twist typical of tusks of Mammuthus primigenius Blumenbach in contrast to tusks of the contemporaneous Elephas antiquus Falc. The tusk fragment is therefore believed to originate from a woolly mammoth.

On the surface of Tusk 2, closely spaced fine striation is found on the ventral part of the specimen. The striation is mostly parallel to the length direction of the tusk fragment, but it does not follow the curvature of this. A few coarser and deeper striae (appr. $1 \mathrm{~mm}$ deep, $5 \mathrm{~mm}$ wide and $5-10 \mathrm{~cm}$ long) are found on the ventral side of the specimen, too. These are found at slight angels to the center line of the tusk. Erosional marks like short striae and small grooves, some a few $\mathrm{mm}$ deep, are found here and there on the surface. In some places the fine striation intersects with the coarse striation and the other erosional marks. Here the fine striation is clearly the youngest one.

The greatly curved tusks of woolly mammoths often show wear facets on their ventral surfaces, which according to some authers (as e.g. Kurtén \& Anderson 1980:354), indicate that they were used in scraping snow and ice off the vegetation (see however Krause 1978, who suggests a number of other explanations). Striation derived from such scraping would be transverse to the length direction of the fragment and would mostly occur on a "facet" of it. The striation on this Brorfelde tusk fragment does clearly not result from snow shovelling, because the striation is mostly parallel to the length direction of the tusk fragment. The surface features on Tusk 2 look like glacial marks and are most probably of post mortal origin. Post mortal transport might have been either glacial, fluvioglacial, fluvial, or a combination of these. The rather tough handling of the specimen in the gravel sorting machinery, may also be responsible for some of these marks. The fine parallel striation resembles glacial striae. However, glacial striae would not be evenly distributed on the ventral part of the tusk fragment surface, but rather found on a facet. Thus, the most probable esplanation is that the striation originates from sanding down the ventral part of the tusk fragment, made by Poul Andersen, who found the fragment.

The specimen is broken at both ends. It is massive, i.e. there is no open pulp-cavity. The fragment most probably derives from the part of the tusk distal to the pulp-cavity and proximal to the curved part of the tusk. Tusks are built up of hard layers of dentine in a cone-in-cone structure, interspaced by less compact layers. During weathering of detached tusks, the dentine layers may separate from one another. In the generally well preserved Brorfelde Tusk 2, the central part consists of light yellow zones of non-porous hard dentine layers each zone being $1 / 2 \mathrm{~cm}$ thick and separated from other such zones by minute, looser weathering zones. The preservation at the 


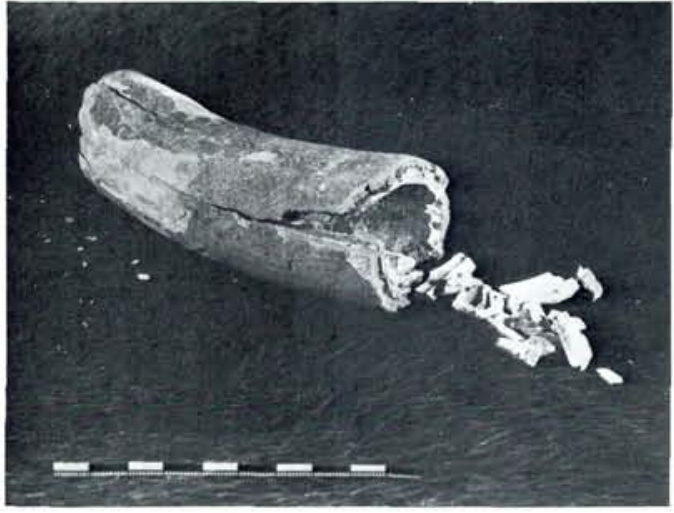

Fig. 2. Elephantine tusk fragment (Tusk 3) found 1969 in Mogenstrup Gravel and Mortarworks, Brorfelde, northwestern Sjalland, Denmark. The length is about $16 \mathrm{~cm}$. Photo: $\mathrm{R}$. Johnsrud, Archaeological museum in Stavanger.

proximal tusk end with oblique fracture was, however, poor when found, with partial solution. The tusk fragment is not conserved, and is kept at the Zoological Museum, Copenhagen.

Tusk 3 (fig. 2) was found in 1969 (also in the gravel sorting machinery) in the Brorfelde gravel pit and thus presumably originates form the fluvioglacial deposits. The tusk fragment is broken at both ends. The length is about $16 \mathrm{~cm}$ and the maximum diameter of the cross-section (oval) at each end is $5 \mathrm{~cm}$ and $6 \mathrm{~cm}$ respectively. As for Tusk 1 it is impossible to conclude from the morphology of the tusk fragment whether it derives from Mammuthus primigenius Blumenbach or from Elephas antiquus Falc. The fragment is poorly preserved. It is conserved and is kept by Svend Andersen, Brorfelde.

\section{Radiocarbon dating of the well preserved Tusk 2}

The well preserved mammoth tusk fragment, Tusk 2, has been subjected to radiocarbon dating four times at the Radiological Dating Laboratory in Trondheim, Norway. Samples T-2275B, C and $\mathrm{D}$ were taken from the light yellow, hard, nonporous dentine part including the minute, looser weathering zones of the tusk fragment, where preservation was good (fig. 3), while sample T-2275A only consisted of the light yellow, hard non-porous dentine part. The dates were obtained from $50-150 \mathrm{~g}$ of tusk material. The yield of organic carbon was $5-10 \%$. The results of the four datings are respectively:

1) $\mathrm{T}-2275 \mathrm{~A}$ collagen fraction $38000_{-1200}^{+1400}$ years B.P.

2) $\mathrm{T}-2275 \mathrm{~B}$ collagen fraction $46300_{-2300}^{+3200}$ years B.P.

3) $\mathrm{T}-2275 \mathrm{C}$ total organic fraction $42000_{-1300}^{+1500}$ years B.P.

4) $T-2275 \mathrm{D}$ collagen fraction $43100_{-1300}^{+1500}$ years B.P.

Results are reported in conventional ${ }^{14} \mathrm{C}$ years before 1950 (years B.P.) with one standard deviation. In these datings the value 5570 years for the half-life of ${ }^{14} \mathrm{C}$ was used for the calculation. $95 \%$ of the activity of the NBS (National Bureau of Standards) oxalic acid standard in the year 1950 has been used as standard.

Sample T-2275A (fig. 3) was from a $0.5-1 \mathrm{~cm}$ thick and $5 \mathrm{~cm}$ long cylinder of hard, non-porous well preserved dentine, taken $0.5 \mathrm{~cm}$ below the outer surface of the tusk fragment. This dating, which was carried out in 1976, was the first attempt at the Trondheim laboratory to separate and date the pure collagen fraction of such material. Because of some doubt concerning extraction of collagen, the laboratory made another dating two years later (T-2275B).

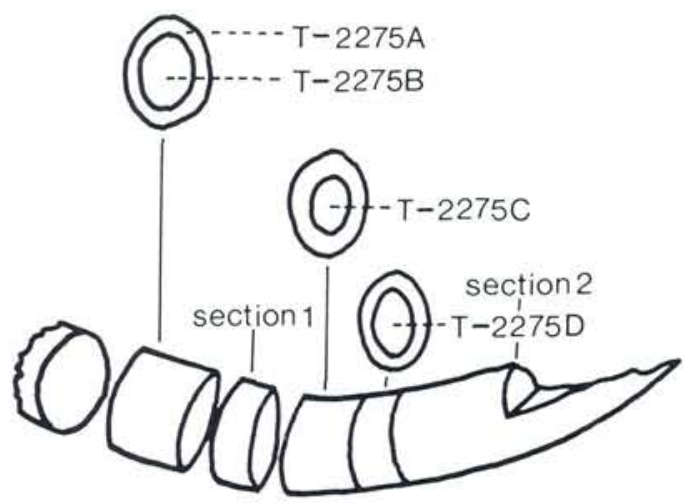

Fig. 3. The figure shows where samples are taken for radiocarbon datings (T-2275A, B, C and D) and for chemical analysis (section 1 and 2). 


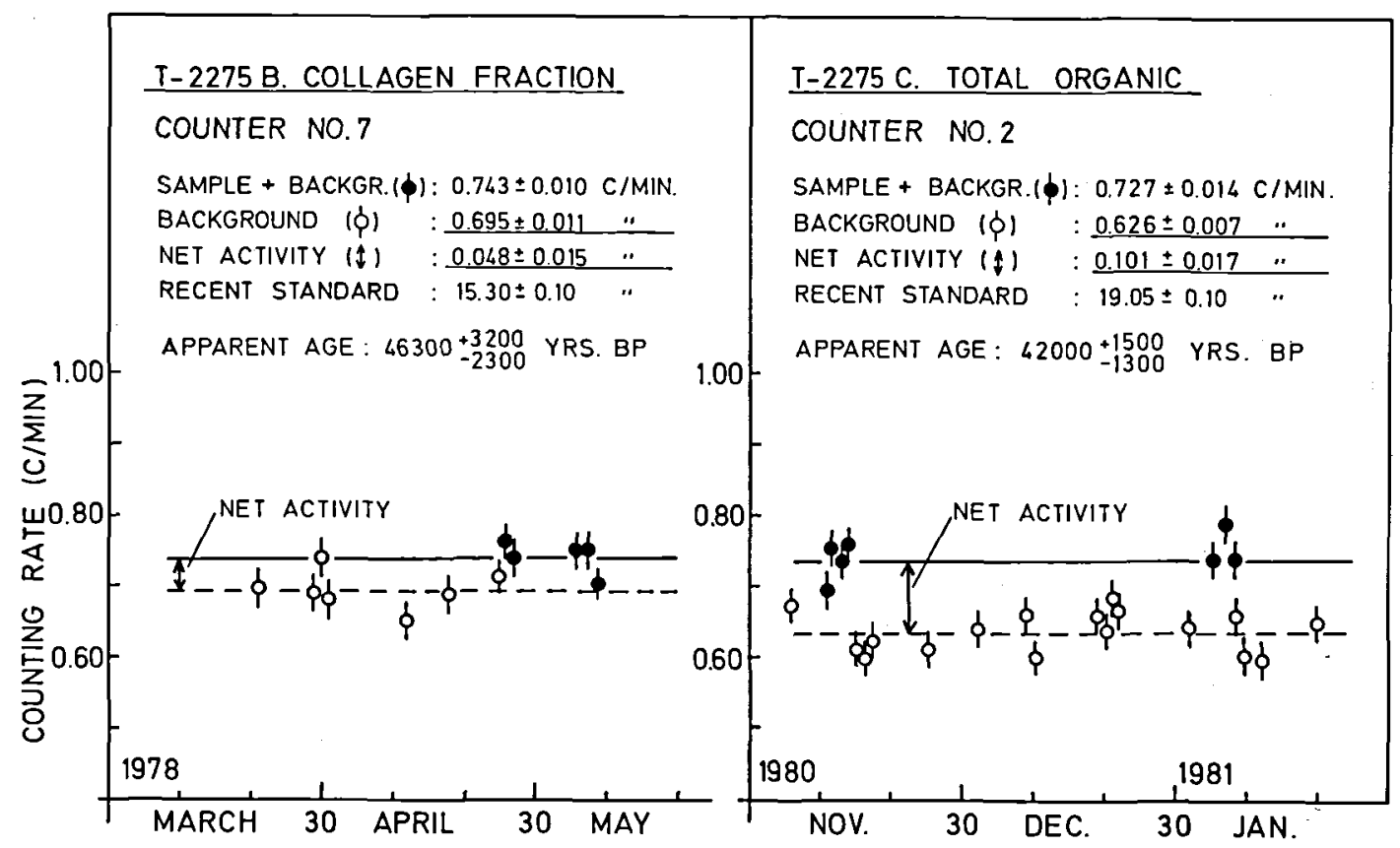

Fig. 4. Counting results on 2 parallel samples with various pretreatment from the mammoth tusk fragment (Tusk 2) from Brorfelde, northwestern Sjælland (from Nydal 1981 fig. 5).

Sample T-2275B constitutes the central part of the disc from which the cylinder for the first date was taken (fig. 3). The superficial contamination was removed by mechanical cleaning, and the sample was then crushed to small grains and powder. The collagen separation procedure follows the method by Longin (1971) as modified by Berglund et al. (1976), i.e. a removal of humic acids by $\mathrm{NaOH}$ is included.

The ${ }^{14} \mathrm{C}$ measurements of sample $\mathrm{T}-2275 \mathrm{~A}$ and $\mathrm{T}-2275 \mathrm{~B}$ were carried out in a 1.5 liter (total volume) gas proportional counter (no. 7), working at 2 atmospheres pressure (Nydal, Gulliksen \& Løvseth 1977). The counting data for this counter applied on sample $\mathrm{T}-2275 \mathrm{~B}$ is given in fig. 4. Single observations including one standard deviation $(1 \sigma)$ are plotted for counting periods of about twenty hours. The resulting apparent age is $46300_{-2300}^{+3200}$ years B.P. The counted age of $\mathrm{T}-2275 \mathrm{~B}$ turned out to be greater than that of $\mathrm{T}-2275 \mathrm{~A}$. Thus, the apparent age of T-2275B may represent a true age, or it may be too low due to contamination with younger carbon.

To evaluate possible contamination, a third sample was dated (T-2275C). This sample was col- lected from the core of the tusk like T-2275B, but in a disc next to the disc used for chemical analysis (section 1, fig. 3). The sample was treated with $50 \% \mathrm{HCl}$ in order to dissolve and remove the carbonate fraction. The residue, the total organic fraction, was further washed in destilled water, dried and combusted to $\mathrm{CO}_{2}$. The procedure used when dating the total organic fraction (T-2275C) includes agents of contamination. The ${ }^{14} \mathrm{C}$ measurements were performed in a gas proportional counter (no. 2) with a total volume of 1.9 liter. The counting result of the total organic fraction shows a clear net activity with an apparent age of $42000_{-1300}^{+1500}$ years B.P.

The age of the third dating (T-2275C) compared with the age of the second dating ( $T$ $2275 B$ ) indicates little or no contamination. In order to be convinced that the age of $\mathrm{T}-2275 \mathrm{~B}$ is really true and to prove that the age can be reproduced, an additional collagen sample T-2275 D has been dated. Sample T-2275D was collected from the core plus the cylinder surrounding the core (fig. 3 ). The procedure used for separation collagen was the same used on the second dating ( $\mathrm{T}-2275 \mathrm{~B})$. The ${ }^{14} \mathrm{C}$ measurements were performed in the same gas proportional counter 
as the third date $(\mathrm{T}-2275 \mathrm{C})$. The age is $43100_{-1300}^{+1500}$ years B.P. (T-2275D). This date confirms that the $\mathrm{T}-2275 \mathrm{~B}$ collagen date, $46300_{-2300}^{+3200}$ years B.P., can be reproduced within an interval of 1 standard deviation.

\section{Discussion}

Radiocarbon datings on mammoth remains, like the Brorfelde tusk fragment, often give ages close to the application limit of the radiocarbon dating method. The absence of proper dating methods beyond some $40000-50000$ years B.P. is a shortcoming in control of the datings. This is the major reason why redating of the mammoth tusk fragment from Brorfelde has been carried out on the collagen fraction (T-2275 B and D) and on the total organic fraction ( $\mathrm{T}-2275 \mathrm{C}$ ) respectively to calculate the possible degree of contamination. Heintz et al. (1979: 217) give evidence for increasing age of fossilbones, molars and tusks with more carefully purifying of the collagen of the samples. It is a question whether the apparent age of the Brorfelde tusk fragment is caused by a last little rest of contamination not removed by the collagen separation procedure or whether it is a finite age.

The first Brorfelde date, $38000_{-1200}^{+1400}$ years B.P. (T-2275A) is really younger than the other dates. This younger date may be caused by contamination of the Brorfelde specimen from younger carbon. Such contamination in the collagen fraction of T-2275A should by no means be greater than that found in the total organic fraction of T-2275C. The age of T-2275A is, however, greater than that found in the total organic fraction of T-2275C. Therefore most probably the result of $\mathrm{T}-2275 \mathrm{~A}$ indicates a laboratory mishap because of some doubt concerning extraction of collagen (Nydal, pers. comm.).

When dating the total organic fraction, contamination by younger carbon is included. Various results have been obtained when dating the total organic fraction of the samples. For the Siberian mammoths (Nydal 1962) the contamination calculated was in most cases small. It was, however, difficult to be convinced about the reliability of the apparent age the age of the animals therefore was given greater than a lower limit. For the Norwegian mammoths, however, the de- gree of contamination turned out to be much greater in several cases than previous assumed (Heintz et al. 1979:216). This was discovered when the bone collagen was extracted for dating. In 2 cases the dating of pure collagen compared to those obtained on the total organic fraction increased the age from ca. 20000 years to more than 45000 years. The dating $42000_{-1300}^{+1500}$ years B.P. (T-2275C) on the total organic fraction of the Brorfelde Tusk 2 is equal with the two collagen dates $46000_{-2300}^{+3200}$ years B.P. (T-2275B) and $43100_{-1300}^{+1500}$ years B.P. (T-2275D) within the limits of error indicating that the contamination with younger carbon is negligible. This statement is based on the assumption that the collagen of the radiocarbon dated samples, T-2275B and D, has been pure. Contamination with only $0.3 \%$ recent carbon will give an apparent age of 46000 years even if the true age of the sample was more than 60000 years old (Nydal, pers. comm.). This indicate that a contamination with only a small amount of younger carbon in the radiocarbon dated Brorfelde specimen will cause an appreciable age error. Contrary, a contamination of $1 \%$ of inactive carbon to an "infinitely old" sample adds approximately 80 years to the age (e.g. Olsson 1974, Taylor 1980). Contamination with material, which has a lower activity than the radiocarbon dated sample, can be excluded when estimating the reliability of the Brorfelde datings.

No mechamism is known by which collagen may be altered to yield a false age (Berger, Horney \& Libby 1964). The collagen separation procedure used when dating $T-2275 B$ and $D$ is the best procedure known to-day purifying the collagen for radiocarbon dating. It is improbable that contamination with non-degraded younger carbon of the Brorfelde Tusk 2 would cause the same error in both the collagen fraction and the total organic fraction. It is suggested that the collagen fraction should give a true age and that the documentation of a finite and reliable age is sufficient after a dating of four independent samples form the Brorfelde mammoth tusk fragment.

The age of the Brorfelde Tusk 2 may be given as the mean value of the two collagen dates, $46300_{-2300}^{+3200}$ years B.P. (T-2275B) and $43100_{-1300}^{+1500}$ years B.P. (T-2275D), calculated on the measured activities. The result of the mean value is $44300_{-1200}^{+1400}$ years B.P. This is the first time a Danish mammoth tusk fragment has been 
radiocarbon dated. The age suggests that the Brorfelde specimen originates from a mammoth which lived in an interstadial periode in Middle Weichselian. This age is postulated by Berglund et al. (1976:187) for many of the Danish mammoth finds, since the whole area belongs to the oscillating marginal zone of the Scandinavian inland ice.

Berglund et al. (op.cit.: 188 table 2) list finite mammoth dates from Europe and Siberia. It is obvious that the Brorfelde tusk fragment is older than the dates in this table except one questionable bone date from Lillehammer, Gudbrandsdalen. Mammoth dates from Norway (Heintz et al. 1979:224 table 1) show older ages, most of them infinite. The age of the Brorfelde Tusk 2 is in accordance with the apparent ages stated for two of the Norwegian Mammoths.

Deposits radiocarbon dated to the same age as the Brorfelde specimen, were demonstrated in Denmark for the first time by Lykke-Andersen (1981) dating a peat layer in Older Yoldia Clay at Hirtshals coast cliff to $47300_{-1200}^{+1500}$ years B.P. (GRN-date) (see also Lykke-Andersen 1982). Deposits correlated with the radiocarbon dated Hirtshals Older Yoldia Clay are found at Holmstrup (Petersen \& Buch 1974) about $15 \mathrm{~km}$ west of Brorfelde. The water supply borings in the files of the Geological Survey of Denmark at three localities in the vicinity north, west and south of Brorfelde (Sdr. Jernløse, archive no. 205.320, Søndersted, archive no. 205.420 and Ugerlose, archive no. 205.381 respectively) give evidence of interglacial or interstadial deposits confirmed by Peter Konradi (pers. comm.), who added that the deposits may either be marin or terrestrial. This indicates that deposits of possible Middle Weichselian age are present in the Brorfelde area. Nordmann $(1921,1942)$ pointed out that the Danish mammoth finds give no evidence that mammoths actually lived in Denmark, because the finds originate from glacial sediments and are thus reworked in relation to the sediments in which they are incorporated. The new investigations referred to above suggest, however, a possible Danish origin of the Danish mammoth finds.

In most areas influenced by the northwest European glaciation an early Middle Weichselian interstadial seems to be older than $\mathbf{4 0} 000$ years B.P., e.g. in England (Upton Warren Interstadial;
Coope 1975), Holland (Moershoofd Interstadial; Kolstrup \& Wijmstra 1977), and Norway ( $\mathrm{Ny-}$ gaard Interstadial; Andersen, Nydal, Wangen \& Østmo 1981).

\section{Conclusions}

Considering the uncertainties involved in the dating of old tusk material, the age of the mammoth tusk fragment from Brorfelde (Tusk 2) is given as the mean value of the two collagen dates, $\mathrm{T}-2275 \mathrm{~B}$ and T-2275D, calculated by means of the measured activities. The age is $44300_{-1200}^{+1400}$ years B.P. This finite and most probably reliable date indicates a Middle Weichselian age of the Brorfelde specimen. The deglaciation phase and the succeeding two ice advances recorded in the Brorfelde area are younger than the Brorfelde Tusk 2. The suggested age of this tusk fragment corresponds relatively well with the age of interstadials recorded in other parts of Denmark (Lykke-Andersen 1981), in England (Upton Warren; Coope 1975), Holland (Moershoofd; Kolstrup \& Wijmstra 1977), Norway (Nygaard; Andersen et al. 1981), and in other areas.

Acknowledgements. Svend Andersen, Brorfelde, has kindly sacrificed the well preserved mammoth tusk fragment (Tusk 2) for radiocarbon dating and chemical analysis. Ulrik Møhl, Zoological Museum, Copenhagen, has examined the three Brorfelde elephantine tusk fragments. The datings were performed under the direction of Reidar Nydal and Steiner Gulliksen, Radiological Dating Laboratory in Trondheim. The continued interest of Ulrik Møhl and Reidar Nydal is gratefully acknowledged. My thanks to Per Blystad and Ulrik Møhl for critical reading of the early stages of the manuscript. Further, I am especially grateful to Ella Hoch and Reidar Nydal for their constructive criticism of this later manuskript. To all these persons I proffer my sincere thanks. I also wish to thank my colleagues at the Archaeological museum in Stavanger for their help.

\section{Dansk sammendrag}

I Mogenstrup grus- og singelværk, Brorfelde i NV-Sjælland, er der fundet brudstykker af tre mammut stødtænder. Et af disse (Tusk 2, Fig. 1) et velbevaret eksemplar, er ${ }^{14} \mathrm{C}$ dateret fire gange. Resultatet af disse dateringer er: $38000_{-1200}^{+1400}$ ar B.P. (T-2275A), $46300_{-2300}^{+3200}$ år B.P. (T-2275B), $42000_{-1300}^{+1500}$ år

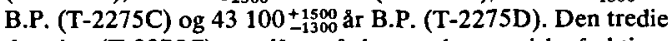
datering (T-2275C) er udført på den totale organiske fraktion, mens de tre andre dateringer (T-2275A, B og D) er udført på kollagen fraktionen. Separering af kollagen er foretaget efter metoden beskrevet af Longin (1971), sådan som den er modificeret af Berglund et al. (1976). 
Problemer med at datere så gamle kollagen-holdige prøver som Tusk 2 fra Brorfelde hænger særlig sammen med muligheden for forurening af proven med yngre karbon fra humussyrer. Ved at datere den totale organiske fraktion inkluderes forurening af yngre karbon, mens datering af kollagen fraktionen udelukker forurening af yngre karbon. Forurening af yngre karbon vil derfor give sig udslag på dateringsresultatet af den totale organiske fraktion (T-2275C). Resultaterne af de tre sidste dateringer ( $T-2275 \mathrm{~B}, \mathrm{C}$ og $\mathrm{D})$ er sammenfaldende indenfor fejlgrænserne fastlagt af en standardafvigelse. Det tyder på, at forurening af yngre karbon sandsynligvis kan udelukkes.

Den første datering (T-2275A) er yngre end de tre sidste dateringer (T-2275B, Cog D). Den første datering (T-2275A) var det første forsøg på at isolere og datere rent kollagen fra denne slags materiale ved Laboratoriet for radiologisk datering i Trondheim. Resultatet af denne datering tyder på, at der er sket en unøjagtighed $\mathrm{i}$ laboratoriet under separering af kollagen (Nydal, pers. medd.).

Den endelige og formodentlig reelle alder på brudstykket af mammut stødtanden fra Brorfelde (Tusk 2) angives som middelværdien af de to kollagendateringer, $T-2275 \mathrm{~B}$ og D. Resultatet er $44300_{-1200}^{+1400}$ å B.P. Dette er første gang levninger fra en dansk mammut stødtand er radiokarbon dateret. Alderen viser, at brudstykket af stødtanden fra Brorfelde (Tusk 2) sandsynligvis stammer fra en mammut, som levede $i$ en tidlig interstadial periode i Midt Weichsel. Denne alder svarer relativt godt til alderen på interstadialer, som er dokumenteret i England (Upton Warren Interstadial; Coope 1975), Holland (Moershoofd Interstadial; Kolstrup \& Wijmstra 1977), Danmark (Lykke-Andersen 1981), Norge (Nygaard Interstadial; Andersen et al. 1981) og $\mathrm{i}$ andre områder.

\section{References}

Andersen, B. G., Nydal, R., Wangen, O. P. \& Østmo, S. R. 1981: Weichselian before 15.000 years B. P. at JærenKarmøy in southwestern Norway. Boreas 10, 297314.

Berger, R., Horney, A. G. \& Libby, W. F. 1964: Radiocarbon Dating of Bone and Shell from Their Organic Components. Science 144, 999-1001.

Berglund, B. E., Håkansson, S. \& Lagerlund, E. 1976: Radiocarbon-dated mammoth (Mammuthus primigenius Blumenbach) finds in South Sweden. Boreas 5, 177-191.

Chaline, J., Mojski, J. E. \& Meyer, K.-D. 1980: Report on the Symposium Vistulian Stratigraphy, Poland 1979. Boreas 9, 151.

Coope, G. R. 1975: Mid-Weichselian climatic changes in Western Europe, re-interpreted from Coleopteran assemblages. R. Soc. New Zealand Bull. 13, 101-108.

Heintz, N., Garnes, K. \& Nydal, R. 1979: Norske og sovjetiske mammutfunn i kvartærgeologisk perspektiv. In Nydal, R., Westin, S., Hafsten, U. \& Gulliksen, S. (eds.): Fortiden $i$ søkelyset, 209-223. Laboratoriet for Radiologisk datering, Trondheim.
Kolstrup, E. \& Wijmstra, T. A. 1977: A palynological investigation of the Moershoofd, Hengelo, and Denekamp interstadials in the Netherlands. Geologie en Mijnbouw 56: 85-102.

Krause, H. 1978: Das Mammut - in Eis und Schnee? 110 pp. Own expense, 7 Stuttgart 40, Kameralamtsstr. 22.

Krog, H. \& Tauber, H. 1974: C-14 chronology of Late- and Post-glacial marine deposits in North Jutland. Geol. Surv. Denmark, Yearbook 1973, 93-105.

Kurtén, B. \& Anderson, E. 1980: Pleistocene Mammals of North America. 442 pp. Columbia University Press, New York.

Longin, R. 1971: New method of collagen extraction for radiocarbon dating. Nature 230, 241-242.

Lykke-Andersen, A.-L. 1981: En ny C-14 datering fra Aldre Yoldia Ler i Hirtshals Kystklint. Dansk geol. Foren. Arsskrift 1980: 1-5.

Lykke-Andersen, A.-L. 1982: Nogle nye C-14 dateringer fra Eldre Yoldia Ler i Hirtshals Kystklint. Dansk geol. Foren. Arsskrift 1981: 119-121.

Mangerud, J. \& Berglund, B. E. 1978: The subdivision of the Quaternary of Norden: a discussion. Boreas 7, 179-181.

Nordmann, V. 1921: Nyere Fund af Elefant-Levninger i Danmark. Medd. dansk geol, Foren. 6, 1-17.

Nordmann, V. 1942: Tillæg I til "Nyere Fund af Elefant-Levninger i Danmarkк. Medd. dansk geol. Foren. 10, $167-177$.

Nydal, R. 1962: Trondheim Natural Radiocarbon Measurements III. Radiocarbon 4, 160-182.

Nydal, R. 1981: Optimal number of samples and accuracy in dating problems. Proc. first international symposium on C-14 and archaeology, Groningen, August 24-28, 1981, 1-24.

Nydal, R., Gulliksen, S. \& Lovseth, K. 1972: Trondheim natural radiocarbon measurements VI. Radiocarbon 14, 418-451.

Nydal, R., Gulliksen, S. \& Lovseth, K. 1977: Proportional counters and shielding for low level gas counting. Proc. int. conf. on low-radioactivity measurements and applications, 6-10 October 1975, The High Tatras, Czechoslovakia, 7784. Bratislava 1977, Slovenské Pedagogické Nakladatelstvo.

Olsson, I. U. 1974: A critical analysis of ${ }^{14} \mathrm{C}$ datings of deposits containing little carbon. Proc. 8th Int. Conf. Radiocarbon dating, Lower Hutt, Oct. 18-25, 1972. R. Soc. New Zealand, Wellington, 547-564.

Petersen, K. S. \& Buch, A. 1974: Dislocated tills with Paleogene and Pleistocene marine beds. Tectonics, lithology, macro- and microfossils. Danm. Geol. Unders. Arbog 1973, 63-91.

Selsing, L. in prep.: Late Weichselian stratigraphy in the Brorfelde area, Denmark.

Sollid, J. L. 1969: A 48000 years old tree stump, presumably of spruce, found in Ringerike, South Norway. Norsk geogr. tidsskr. 23, 131-133.

Taylor, R. E. 1980: Radiocarbon Dating of Pleistocene Bone: Toward Criteria for the Selection of Samples. Radiocarbon 22, 969-979. 